\title{
NOISE-INDUCED HEARING LOSS IN CHILDREN AND ADOLESCENTS: A REVIEW
}

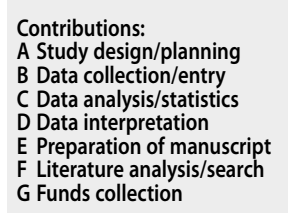

A Study design

B Data collection/entry

C Data analysis/statistics

D Data interpretation

F Literature analysis/search

G Funds collection

\section{Pamela Daria Świerczek ${ }^{\mathrm{B}, \mathrm{D}-\mathrm{F}}$, Agata Sochań ${ }^{\mathrm{B}, \mathrm{D}-\mathrm{F}}$, Kornelia Kędziora-Kornatowska ${ }^{\mathrm{D}, \mathrm{F}}$}

Department and Clinic of Geriatrics, Ludwik Rydygier Collegium Medicum in Bydgoszcz, Nicolaus Copernicus University in Toruń, Poland

Corresponding author: Pamela Daria Świerczek, Department and Clinic of Geriatrics, Ludwik Rydygier Collegium Medicum in Bydgoszcz, Nicolaus Copernicus University in Toruń, Jagiellońska 13/15, 85-067, Bydgoszcz, Poland; email: pswierczek07997@gmail.com, Phone: +48536320188

\begin{abstract}
Hearing loss is becoming more frequent, especially in developing and highly developed countries. Progressive hearing loss is commonly a result of noise. Sources are often found in industry, but they also occur as environmental noise associated with the use of various types of transport. In children and adolescents, the biggest threat is recreational noise, i.e. music on headphones, concerts, discos, and toys. Noise not only affects the hearing of children, weakening it and increasing susceptibility to hearing loss in later years, but it also has so-called extracoustic effects. These include disturbed sleep, concentration, aggressive behavior, stress, and anxiety. Hearing loss arising from noise primarily affects high frequencies, reducing the ability to understand speech. This causes, among others, problems with speech development, education, and communicating with peers, which is why it is important to prevent hearing loss and to diagnose the problem as soon as possible. The aim of this work was to present the most important information on hearing loss caused by noise in the environment of children, and to show the social extent of the problem.
\end{abstract}

Key words: children $\bullet$ noise $\bullet$ hearing loss $\bullet$ sensorineural hearing loss

\section{USZKODZENIE SŁUCHU U DZIECI I MŁODZIEŻY SPOWODOWANE HAŁASEM - PRZEGLĄD}

\section{Streszczenie}

Niedosłuch spowodowany hałasem jest coraz częstszym zjawiskiem, przede wszystkim w państwach rozwijających się oraz w tych wysoko rozwiniętych. Niedosłuch jest skutkiem coraz powszechniej występującego hałasu. Jego źródłem jest najczęściej przemysł, lecz także jesteśmy narażeni na hałas środowiskowy między innymi podczas korzystania z różnego rodzaju środków lokomocji. W grupie dzieci i młodzieży największym zagrożeniem jest hałas związany z rekreacją, czyli słuchaniem muzyki przez słuchawki, koncertami, dyskotekami oraz zabawkami. Wpływa on nie tylko na stan słuchu dzieci - osłabia go oraz zwiększa prawdopodobieństwo powstania niedosłuchu w późniejszych latach, lecz także powstają tak zwane pozasłuchowe efekty działania hałasu. Obejmują one: zaburzenia snu, koncentracji, powstawanie zachowań agresywnych, stres oraz niepokój. Niedosłuch, który u dzieci i młodzieży powstał na skutek hałasu, dotyczy przede wszystkim częstotliwości wysokich, przez co obniżona zostaje zdolność do rozumienia mowy. Powoduje to między innymi problemy z rozwojem mowy, nauką w szkole, nawiązywaniem kontaktów z rówieśnikami. Dlatego tak ważne jest, by nie dopuszczać do możliwości powstania niedosłuchu oraz, jeśli wystąpi, jak najszybciej zdiagnozować problem. Celem pracy było przedstawienie najważniejszych informacji na temat niedosłuchu spowodowanego hałasem w środowisku dzieci i młodzieży oraz ukazanie tego zjawiska jako problemu społecznego, który można określić jako plagę dzisiejszych czasów.

Słowa kluczowe: dzieci • hałas $\bullet$ niedosłuch $\bullet$ niedosłuch odbiorczy

\section{Introduction}

Noise-induced hearing loss is a hearing loss characterized by being bilateral and permanent. Most often it appears among the elderly, who have working for many years in a profession subject to noise exposure. Noise can be understood as all sounds harmful to human health or undesirable in a given place and time [1]. In recent years, lifestyle changes, increasing urbanization, and increasing traffic have caused an increase in overall environmental noise. Due to these factors, noise-induced hearing loss is increasingly common in children and adolescents [2]. Uncompensated hearing loss in children can contribute to problems with speech development, concentration, language learning, or behavioral disorders. The greater the hearing loss, the greater the observable delays in school learning [3]. Noise-induced hearing loss cannot be cured at the moment, which is why prevention is so important [4].

\section{Material and methods}

This paper is a systematic review of the literature published between 2001 and 2020, although most of the articles were 2010 to 2020. The articles were selected from searches on PubMed and Google Scholar. The most common terms that were used when searching for materials were noise-induced hearing loss and hearing loss. Keywords were searched in both Polish and English. The terms accorded with the Medical 
Subject Heading (MeSH) terms. A PRISMA review form was compiled (http://prisma-statement.org/prismastatement/ Checklist.aspx). The criteria for rejecting or accepting papers were based on the relevance and reliability of the articles and our own academic knowledge. A flow diagram of the systematic review is shown in Figure 1.

\section{Characteristics of noise-induced hearing loss}

The negative impact of noise on the human hearing organ depends on factors such as the volume of the sound, its character, duration, and individual susceptibility. High levels of sound can cause hearing damage after a single exposure and this loss is called acute acoustic trauma [5]. Most often, such trauma occurs in people who have contact with firearms at work, where acoustic energy of 160 $190 \mathrm{~dB}$ can be released [6]. More commonly, lower levels of exposure are repeated many times over many years, so that even moderately low-level sounds can cause hearing loss (called chronic acoustic trauma). Noise initially causes temporary threshold shift (TTS), which is a reversible hearing impairment. If exposure to TTS is repeated, this can lead to permanent threshold shift (PTS), i.e. irreversible hearing damage $[5,7]$.

Noise-induced hearing loss is characterized by a defect initially arising in the $4-6 \mathrm{kHz}$ band and over time deepens and expands to neighboring frequencies. In addition, in the first years of illness there is the presence of loudness recruitment. The biggest jump in hearing loss occurs during the first years of exposure, after which its development slows down $[8,9]$.

\section{Sources of noise and its intensity in the child's environment}

Children are exposed to noise from the very first moments after birth. Before birth, the hearing organ is protected from excessive sounds by the amniotic fluid and maternal abdominal tissues, which act as a filter that reduces the intensity of sounds from the environment by about 20-35 dB. After birth, when the amniotic fluid is no longer present, the baby is susceptible to loud sounds. Such sounds can be generated by various types of machines or people in the newborn's surroundings, but is most likely to be in the incubator. Closing the incubator's windows, tapping on its walls, or conversations of people in the surroundings generate sounds at a level of around 80-90 dB, so a long-term stay exposes the baby to potential hearing loss. In the important first days of life it can also reduce the respiratory capacity of the lungs, lead to disorders of the cardiovascular system, or disturb sleep. The highest exposure group are premature babies who require hospitalization for up to several months $[10,11]$.

As a child gets older, they start playing with toys that can help them grow. However, some toys generate sounds that are harmful to hearing. For example, a toy radio or telephone
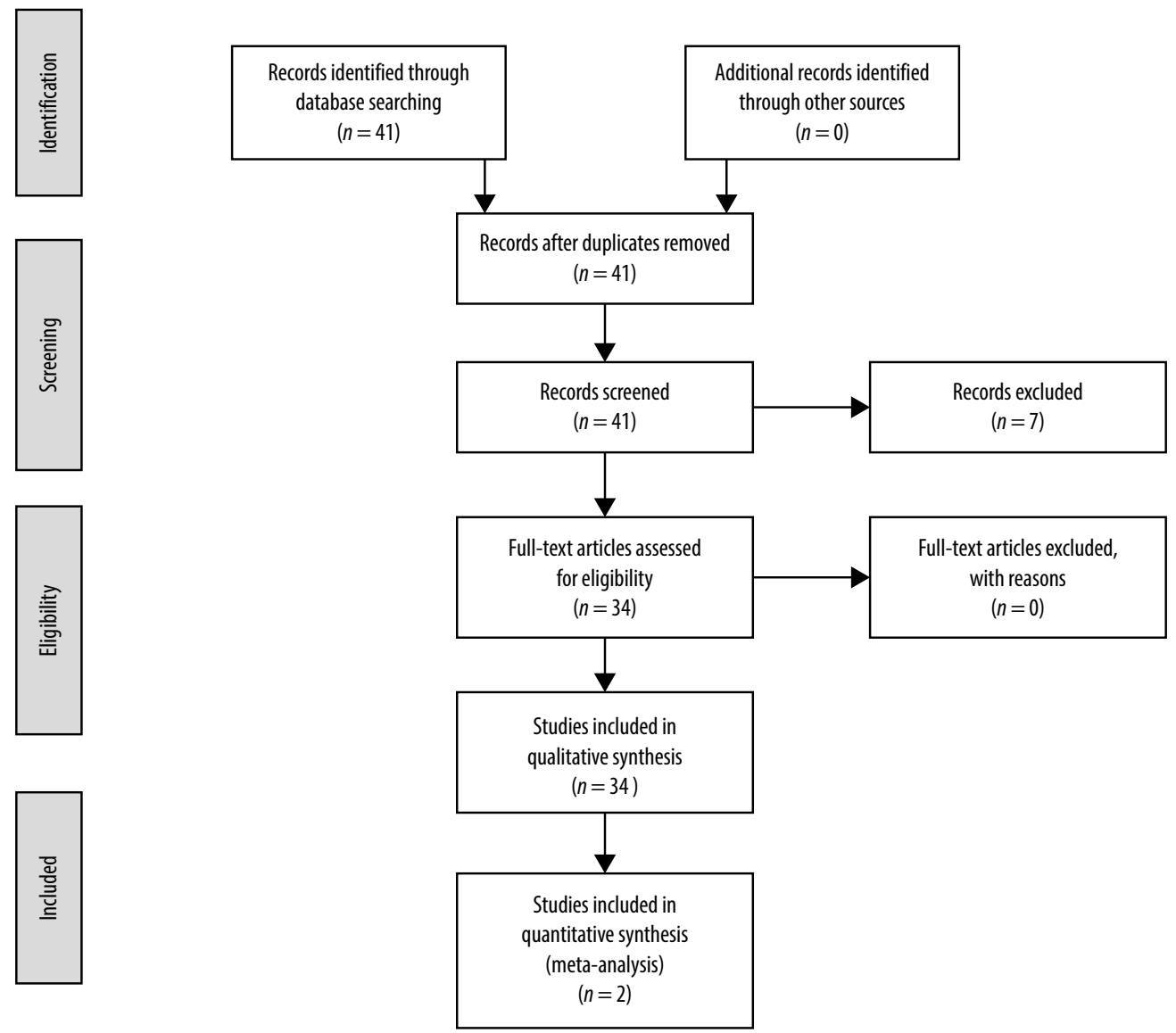

Figure 1. PRISMA flow diagram 
generates sounds at a level of about $60 \mathrm{~dB}$ at a distance of $30 \mathrm{~cm}$ from the child's head, music boxes can reach an intensity of up to $75 \mathrm{~dB}$, while toy musical instruments such as a guitar up to $90 \mathrm{~dB}$. Many toys produce dangerously loud sounds in the 500 to $4000 \mathrm{~Hz}$ band, which coincides with the speech band and the range of highest hearing sensitivity. Hearing damage in such a band can cause a problem in speech understanding [12].

High levels of sound also occur in schools. The main source of noise there are sounds coming from the surroundings of the facility. Most schools are located in places where the noise level can reach $65 \mathrm{~dB}$. Similar levels can be recorded in a school playground, where children are during breaks or physical education classes. However, the most harmful place at school is usually the corridors, where noise levels there during breaks are 66-98 dB. Lower sound levels are found in classrooms, which range from 53 to $75 \mathrm{~dB}$; however, although they are quieter, it has the potential to affect students and teachers the most, diminishing the ability to focus on learning, and increasing irritation and irritability [13].

The next stage of exposure to noise is teenagehood. Although listening to music does not quite fit the definition of noise, because these are desirable sounds, their long-term impact on hearing can also cause hearing disorders typical of noise damage. Currently, around $88-90 \%$ of teenagers and young adults declare they listen to music through headphones, and the percentage of people attending concerts increases every year. Music played on headphones can reach up to $120 \mathrm{~dB}$ when the preferred gain is between 68 and $86 \mathrm{~dB}$. There is a percentage of young people whose listening habits may affect their hearing [14].

\section{Prevention in the child's environment}

Because of differences in ear anatomy, children and teenagers are more sensitive to noise than adults. Early exposure to noise can lead to earlier and larger hearing damage, which eventually becomes apparent in old age as presbyacusis. That is why prevention is very important. After many studies which found that large percentages of children are subject to long-term noise exposure, the European Action Plan for the Environment and Children's Health was created, which provides tips and guidelines to improve and monitor the environment and health of children. In addition, a group of experts created a document called PINCHE, which contains principles for the prevention of acoustic trauma in children [15].

According to these programs, the most important thing is to reduce noise in schools by systematically measuring it both from outside and inside the institution, and by applying knowledge of acoustic adaptation and the possibility of using noise protection measures so that class-room sounds do not exceed $35 \mathrm{~dB}$ unless there is a person in the class who is hearing impaired, in which case sounds should not exceed $30 \mathrm{~dB}$. In addition, lessons should be given about the dangers of noise and their effects on health, with a strong emphasis on knowing how to listen properly to music through headphones and measures to take when going to discos and concerts. The noise level in incubators should be restricted to a maximum of $50 \mathrm{~dB}$. For toys and fireworks, the maximum sound level should be reduced and it should be displayed on the label, with a warning about possible harm to hearing. Personal music players and noise at concerts should be reduced to a maximum of $100 \mathrm{~dB}$ with an indication that $75 \mathrm{~dB}$ is the maximum safe level $[15,16]$.

According to research, attention should be paid not only to the intensity of sound levels, but also to their duration. In 1998, the National Institute for Occupational Safety and Health indicated that $85 \mathrm{~dB}$ was the maximum safe level for 8-hour exposure. The exchange principle was also set out, where if the noise duration is shortened or extended, its safe level is increased or decreased accordingly. According to this rule, listening to $91 \mathrm{~dB}$ music is safe for 2 hours, for $100 \mathrm{~dB}$ it will be 15 minutes, while for $103 \mathrm{~dB}$ only some 7 minutes a day. Repeatedly exceeding these norms leads to hearing loss. However, there may be situations where these maximum levels will still be too high. Therefore, during concerts, you should properly protect yourself by staying at a safe distance from the speakers to reduce the intensity of the sounds reaching the ears or wear ear protectors, both there and in clubs and during sporting events [17]. In addition, some researchers indicate a good effect of using headphones with sound isolation, because it has been shown that a higher background level in the environment leads to the use of higher levels of sound in the headphones [18].

\section{Detection of noise-induced hearing loss}

To detect and categorise a given level of hearing damage, a number of tests are needed, the results of which will confirm the existence of hearing loss, as well as its depth, type, and degree. Studies that allow diagnosis of noise-induced hearing loss include anamnesis, pure tone audiometry, suprathreshold audiometry, and otoacoustic emissions [19].

Anamnesis, i.e. patient history, is the first activity the examiner performs when diagnosing hearing loss. The interview must be comprehensive and include questions about the profession and the background sound that accompanies the patient during work. Another important aspect is contact with ototoxic substances, because acquired hearing loss can be significantly aggravated by these substances and can amplify normal hearing loss from damage caused by noise. Another key question for the patient is a request to characterize their symptoms. Noise-induced hearing loss is characterized by bilateral hearing loss, not exceeding a level over $60 \mathrm{~dB}$, that has increased steadily over a number of years. Tinnitus is also a frequent consequence of hearing damage due to noise $[19,20]$. When conducting anamnesis, it is important to determine comorbidities. Hearing loss can be caused by previous otitis, middle ear surgery, ingestion of ototoxic drugs, or head injury. The occurrence of such trauma is also favored by the occurrence of such ailments as kidney disease, diabetes, hypertension, rheumatoid arthritis, or a genetic predisposition to the emergence of this pathology [19].

Pure tone audiometry is the most common hearing test used to determine hearing thresholds. As a result of noiseinduced hearing damage, the audiogram will likely show most hearing impairment at $4000 \mathrm{~Hz}$ [21], although the result will depend on the time of exposure to noise and the age at which the patient was most exposed to noise. After 
15 years of exposure to very loud sounds, hearing loss flattens by deterioration of hearing thresholds at other frequencies, followed by stabilization $[19,21]$.

Suprathreshold audiometry is used to assess hearing levels at a volume exceeding threshold. To confirm hearing loss due to noise, a SISI test or Metz symptom should be performed. This hearing damage is a cochlear type injury. When performing these tests on a patient with this type of hearing impairment, the results are positive. The SISI test is particularly characteristic for the initial period of injury [19].

Otoacoustic emission is an objective study which examined the functioning of outer hair cells [22]. Noise has a destructive effect primarily on the outer hair cells, which is why during a test in a person with hearing impairment caused by noise, the otoemission record disappears for $3000-5000 \mathrm{~Hz}$ $[21,23]$. Joint performance of otoacoustic emission and pure tone audiometry is crucial because audiometry determines the degree of hearing loss, and otoacoustic emission shows damage of the hearing cells. However, some researchers believe that otoacoustic emission of non-linear distortion products catches differences in hearing faster and is more sensitive to hearing changes due to significant noise exposure than from pure tone audiometry $[21,24]$.

\section{Treatment of noise-induced hearing loss}

Oxidation of the hearing organ plays an important role in the perception of sounds. For the cochlea to operate properly it must be supplied with the right amount of oxygen and other energy-generating substances. The occurrence of acoustic trauma and exposure to noise reduces the amount of oxygen in the fluids of the inner ear appreciably. The use of hyperbaric oxygen as a means of treating acoustic trauma seeks to increase oxygen supply to the inner ear. Oxygen hyperbaria involves respiring $100 \%$ oxygen at increased ambient pressure [25], causing a major increase in oxygen pressure in the cochlea. The use of oxygen hyperbaria is considered effective in the treatment of acoustic trauma and sudden sensorineural hearing loss. Currently, treatment of noiseinduced hearing loss is based on the administration of steroids and hyperbaric therapy. However, these approaches are not sufficient to treat traumas caused by noise $[25,26]$.

Because it is not possible to revive or replace damaged hearing cells, researchers have begun to look for ways to protect the cochlea from high noise or to reduce free-radical production. Apoptosis and necrosis are the most important pathophysiological processes in the cochlea. Apoptosis is the enzymatic destruction of auditory cells, and necrosis is the destruction of cells by damage to the cell membrane and the appearance of inflammation [27]. Apoptosis begins as soon as acoustic trauma occurs and works as a mitochondrial pathway that is activated by oxidative stress. Measures to prevent the occurrence of apoptosis and necrosis stop the formation of free radicals and damage to hearing cells, but these practices are currently still in an active research phase [27].

Another direction of modern research is the development of a kinase-blocking drug that can be administered prior to exposure to sudden sounds. Coleman et al. found protective properties of the drug AM-111 for the inner ear [28]. This drug can be given by intrathecal administration before exposure to acoustic trauma, or even 4 hours after. Suckfuell and colleagues have shown that the drug is effective when administered up to 24 hours after acoustic injury $[29,30]$. Various views on the effects of AM-111 show that there are still no precise guidelines for the treatment of acoustic trauma, and prevention information is still under study. The scientific world has high hopes for this drug and is considered to offer great potential for people who are exposed to noise.

\section{Discussion}

The aim of the work has been to present important information on noise-induced hearing loss in the context of children's hearing and to show the social extent of the problem, one which might be described as a modern-day scourge. The current literature shows that children are exposed to noise from the first years of life [31], and the spread of modern music playback devices, and the popularity of cell phones, means an increase in the likelihood of teenagers damaging their hearing from loud music [32]. In situations where young people are exposed to noise, prevention of hearing loss should involve the use of hearing protectors, while diagnosis and monitoring of hearing should be based on pure tone audiometry [16]. According to some recent publications, hyperbaric oxygen is a useful method of improving auditory function in the face of hearing damage due to noise [33]. Current research suggests that the drug AM-111 has a protective effect on the inner ear and can be used as a preventive and therapeutic agent in dealing with hearing damage from noise [34].

\section{Conclusions}

Hearing damage caused by noise is a serious problem among children and adolescents. Young people have to deal with noise from the first days of life. The danger of hearing damage begins from the moment they are placed in the incubator, followed by noise-making toys, screaming in school corridors, and excessive sound levels while listening to music over headphones. Due to differences in the anatomical structure of the ear, children and adolescents are more sensitive to noise than adults. Preventive programs can help reduce noise in everyday life of young people. Hearing loss due to noise can be treated by hyperbaric oxygen and the use of pharmacological agents. However, in order to apply appropriate treatments for hearing loss, it is first necessary to carry out hearing diagnostics based on subjective and objective tests.

\section{References}

1. Kantor I, Usowski J, Jurkiewicz D, Wojdas A, Kiciak J. Hałas w życiu codziennym jako czynnik zagrożenia dla człowieka. Annales Universitatis Mariae Curie-Skłodowska Lublin - Polonia, 2005; 60(16): 339-41.
2. Imam L, Hannan SA. Noise-induced hearing loss: a modern epidemic? Br J Hospit Med, 2017; 78(5): 286-90. 
3. Obrębowski A, Hojan E. Uwagi w sprawie obustronnego niedosłuchu minimalnego w wieku szkolnym. Otorynolaryngologia, 2014; 13(4): 181-5.

4. Sułkowski W, Owczarek K, Olszewski J. Contemporary noiseinduced hearing loss (NIHL) prevention. Otolaryngol Pol, 2017; 71(4): $1-7$.

5. Dudarewicz A, Zaborowski K, Wolniakowska A, PawlaczykŁuszczyńska M, Śliwińska Kowalska M. Evaluation of on-the-job noise exposure in the case of bartenders. Medycyna Pracy, 2018; 69(6): 633-41.

6. Amernik K, Kabacińska A, Tarnowska Cz, Paradowska-Opałka B. Ostry uraz akustyczny i termiczny ucha spowodowany awarią telefonu komórkowego. Otolaryngol Pol, 2007; 61(4): 484-6.

7. Śliwińska-Kowalska M, Zaborowski K. WHO environmental noise guidelines for the European region: a systematic review on environmental noise and permanent hearing loss and tinnitus. Int J Environ Res Public Health, 2017; 14(10): 1-19.

8. Śliwińska-Kowalska M. Uszkodzenia słuchu spowodowane hałasem. In: Śliwińska-Kowalska M. editors. Audiologia Kliniczna (1t edition). Łódź: Mediton Oficyna Wydawnicza; 2005, 289-98.

9. Dobie RA. 10 facts (and a question) about NIHL and medicallegal evaluation. Hear J, 2018; 17(2): 34-5.

10. Cedrowska-Adamus W, Gulczyńska E. Kontrola poziomu dźwięków na oddziale noworodkowym. Postępy neonatologii, 2018; 24(2): 129-33.

11. Lehman I, Królak-Olejnik B. Dźwięk na oddziale intensywnej terapii i jego wieloaspektowy wpływ na rozwój noworodka. Postępy neonatologii, 2019; 25(2): 115-23.

12. Harazin B. Parametry akustyczne zabawek samogrających. Medycyna Pracy, 2010; 61(6): 649-54.

13. Kolawa S, Hadryś D. Hałas jako czynnik środowiska pracy nauczyciela. Zeszyty Naukowe Wyższej Szkoły Zarządzania Ochroną Pracy w Katowicach, 2016; 1(12): 60-73.

14. Śliwińska-Kowalska M. Używanie osobistych odtwarzaczy muzyki a uszkodzenie słuchu. Otorynolaryngologia, 2013; 12(4): 155-60.

15. Sułkowski WJ. Uszkodzenia słuchu spowodowane hałasem u dzieci i młodzieży: przyczyny i prewencja. Medycyna Pracy, 2009; 60(6): 513-7.

16. Sułkowski W, Owczarek K, Olszewski J. Contemporary noiseinduced hearing loss (NIHL) prevention. Otolaryngol Pol, 2017; 71(4): 1-5.

17. Levey S, Fligor BJ., Ginocchi C, Kagimbi L. The effects of noiseinduced hearing loss on children and young adults. Contemp Issues Commun Sci Disorders, 2012; 39: 76-83.

18. Roberts B, Neitzel RL. Noise exposure limit for children in recreational settings: review of available evidence. J Acoust Soc Am, 2019; 146: 1-28.

19. Śliwińska-Kowalska M, Niebudek-Bogusz E, PawlaczykŁuszczyńska M, et.al. Zasady orzekania o predyspozycjach zawodowych do pracy w narażeniu na hałas lub nadmierny wysiłek głosowy oraz diagnostyka i profilaktyka chorób narządu słuchu i narządu głosu. Centrum Medyczne Kształcenia Podyplomowego, 2001; 1: 53-119.
20. Niedzielski A, Kędzierawska S. Szumy uszne: przegląd aktualnej literatury. Nowa Audiofonologia, 2017; 6(4): 10-11.

21. Le TN, Straatman LV, Lea J, Westerberg B. Current insights in noise-induced hearing loss: a literature review of the underlying mechanism, pathophysiology, asymmetry, and management options. J Otolaryngol Head Neck Surg, 2017; 46(1): 41.

22. Kurabi A, Keithley EM, Housley GD, Ryan AF, Wong A. Cellular mechanisms of noise-induced hearing loss. Hear Res, 2017; 349: 129-137.

23. Mühlmeier G, Schweikert A, Schramm S, Burkart M, Tisch M. Study protocol of the monocentric prospective randomized placebo-controlled double-blind phase II study to explore the protective effects of the ginkgo biloba extract EGb $761{ }^{\circledR}$ from temporary noise-induced hearing loss. HNO, 2020; 68(4): 272-7.

24. Hendler B, Kotyło P, Fiszer M, Śliwińska-Kowalska M. Zastosowanie emisji otoakustycznej produktów zniekształceń nieliniowych w monitorowaniu uszkodzeń słuchu spowodowanych hałasem. Otorynolaryngologia, 2003; 2(1): 27-33.

25. Śliwińska-Kowalska M, Narożny W, Sekula A, et. al. Nagły niedosłuch czuciowo-nerwowy: stanowisko Polskiego Towarzystwa Audiologicznego i Foniatrycznego dotyczące zaleceń diagnostycznych i terapeutycznych. Otorynolaryngologia, 2015; 14(2): 71.

26. Paprocki J, Pawłowska M, Sutkowy P, Piechocki J, Woźniak A. Równowaga oksydacyjno-antyoksydacyjna we krwi osób z nagłym niedosłuchem czuciowo-nerwowym po przeprowadzonym pierwszym zabiegu hiperbarii tlenowej - badanie wstępne. Polish Hyperbaric Res, 2017; 4(61): 4-5.

27. Paduch R, Klatka M, Klatka J. Types of cell death. Pomeranian J Life Sci, 2015; 61(4): 412-5.

28. Coleman J, Littlesunday C, Jackson R, Meyer T. AM-111 protects against permanent hearing loss from impulse noise trauma. Hear Res, 2007; 226(1-2): 70-78.

29. Narożny W, Siebert J, Płończak J. Leczenie zachowawcze niektórych chorób ucha wewnętrznego. Via Medica, 2008; 2(5): 378-90.

30. Suckfuell M, Lisowska G, Domka W, Kabacińska A, Morawski K. Efficacy and safety of AM-111 in the treatment of acute sensorineural hearing loss: a double-blind, randomized, placebo-controlled phase II study. Otol Neurotol, 2014; 35(8): 1317-26.

31. Gupta A, Gupta An, Jain K, Gupta S. Noise pollution and impact on children health. Indian J Pediatrics, 2018; 85(4): 300-06.

32. Le Clercq C, van Ingen G, Ruytjens L, van der Schroeff MP. Music-induced hearing loss in children, adolescents, and young adults: a systematic review and meta-analysis. Otol Neurotol, 2016; 37(9):1208-16.

33. Krajcovicova Z, Zigo R, Melus V. Possibilities of hyperbaric oxygen therapy usage in comprehensive treatment of selected hearing diseases and disorders. University Review, 2015; 9(1-2): 45-53.

34. Eshraghi A, Aranke M, Salvi R, et al. Preclinical and clinical otoprotective applications of cell-penetrating peptide D-JNKI-1 (AM-111). Hear Res, 2018; 368: 86-91. 
